\title{
最近の歯学
}

\section{7. 精密機械}

\section{根管拡大器具切削試験装置の試作}

相宗医科淶科大学医用器材研究所精密機械部門 永 井 正洋

根管治療に際し，根管の清掃払大にはリーマおよびフ ァイルが用いられている。ここで，リーマとファイルで は切削方式が異なっているにもかかわらず，これまでに 試作されてきた切削試験装置は，JIS T5202に準じて切 削器具の回転がそのまま送りネジに伝達される方式を採 用し, このとき切削器具の回転速度を変えても 1 回転当 たりの切削器具移動距離 $\ell_{1}$ は $\ell_{1}=1.5 \mathrm{~mm} / \mathrm{rev}$. と一定 のものであった。そのため, 成先径のかなり小さいもの は，切削開始とともに坐屈を起こし，切削試験を拣施す ることが難しかった。また，妇削性能を評価するたいに は，切削抵抗を测定することが重要となるが、これまで は切削トルクだけを対蚝とし, 切削器具の軸方向の切削 抵抗は測定されていなかった。したがって、リーマもフ アイルについても同様の試験方法により，关机らの切削 性能は評価されてきた。

このような状況を鑑みて，当部門では次に示すような 性能を有する切削試験装说を試作しだ1)。

(1) 器具の1 回転当たりの移㲜距離を変化することが できる(リーマ, Kファイル)。

（2）器具を回転させて，または無回転で被削材に一定 距離だけ送り込んたのた，自動的に，回転している場合 には回転を停止し，引き拢くことができる（K，Hファ イル)。

(3)切削時の切削トルクおよび器具軸方向の力が速続 的に測定できまた記録することができる。

(4) 被削材洞定治具は板原 1 $5 \mathrm{~mm}$ のものをつかも ことができる。

网1，2はリーマ，Kファイルの切削试験例を示した ものでこのとき，リーマはJIS 規格に準じ試験した垷 合であるが，軸力の最大值はほぼ400gf とかなり大きな 值が測定された。このリーマの先端に圧縮荷重を加えた ときの座屈荷重は 400～500gf 程度であることを考える と, JIS で嫢定している $\ell_{1}=1.5 \mathrm{~mm} / \mathrm{rev}$. の送り速度は いくらか早過ぎるのではないだろらか。一方，Kファイ ルの場合は， $\ell_{1}=0.035 \mathrm{~mm} / \mathrm{rev}$. とかなり遐い送り速度 で $5.6 \mathrm{~mm}$ 被削材側に送り込んだが，このとき軸力は反 対に引張力が働く。このように, 送り速度により切削機
構が異なることがわかった。さらに，試験条件を変えた データを蓄積し, その結果を基に, 切削器具の性能を正 確に評価のできる試験方法について今後確立していくこ とが急務となろう。

なお，本装置の機構および性能に関する詳細は文献を 久て頂きたい。

\section{文献}

1) 永井正洋, 他: 根管拡大器具切削試験装置の試 作. 医用器材研報 $19,1985$.

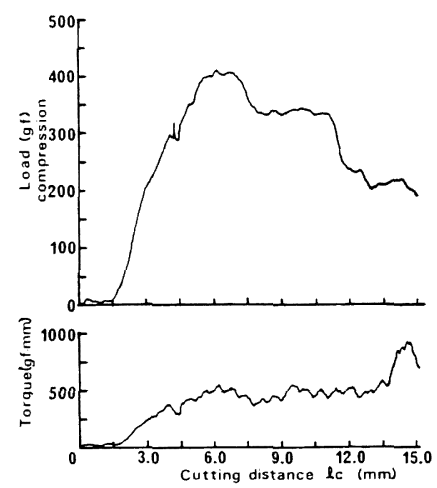

比 1 リーマNo. 35 の切削試験例 : $\ell_{1}=1.5 \mathrm{~mm} / \mathrm{rev} .$, 被削材の板厚 $/$ 下穴径; $1 \mathrm{~mm} / 0.4 \mathrm{~mm}$
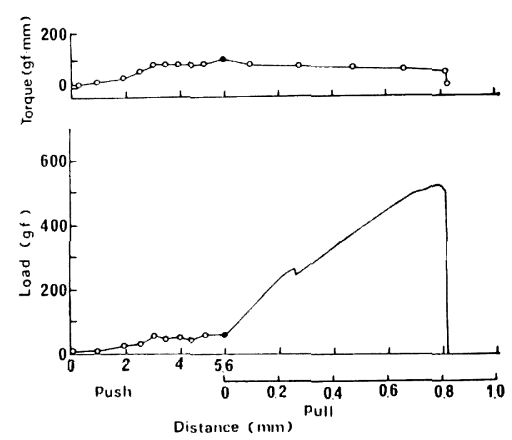

図 2 ファイルNo. 15 の切削試験例 : $\ell_{1}=0.035 \mathrm{~mm} / \mathrm{rev}$. , 引き抜き速度 ; $0.7 \mathrm{~mm} / \mathrm{min}$, 被削材の板厚/下穴径； $3 \mathrm{~mm} / 0.2 \mathrm{~mm}$ 